\title{
NARRATIVA-CARRASCO: KAFKA, ARTAUD E A CRUELDADE
}

\section{HANGMAN-NARRATIVE: KAFKA, ARTAUD AND CRUELTY}

Annita Costa Malufe (PUC-SP)

annitacostamalufe@gmail.com

Matheus Bagaiolo Raphaelli (PUC-SP)

mbraphaelli@gmail.com

\begin{abstract}
RESUMO: O artigo desenvolve o conceito de "narrativa-carrasco", com o objetivo de elucidar uma dinâmica importante da narrativa kafkiana: seu modo de evoluir por meio de uma autodestruição, em um processo de recomeços sem finalização e sem transcendência possivel. Para tanto, parte da ideia de absurdo e busca analisar alguns procedimentos de escrita do autor tcheco que explicitam tal mecanismo, mais detidamente em um de seus contos ("O novo advogado"). Um dos traços fundamentais explorados dessa narrativa-carrasco é aquele de se constituir enquanto saída para o niilismo ocidental. Para tanto, coloca-se em diálogo a filosofia de Nietzsche para chegar-se, ao final, à relação com o conceito de crueldade de Antonin Artaud como chave para compreensão dessa escrita da imanência proposta por Kafka.
\end{abstract}

PALAVRAS-CHAVE: Franz Kafka; crueldade; absurdo; Antonin Artaud.

\begin{abstract}
The article develops the concept of "hangman-narrative" in order to explain an important dynamic of the Kafkian narrative: its particular development through selfdestruction, i.e. a series of beginnings without their corresponding closures and without any possibility of transcendence. Therefore, the article opens with the idea of the absurd and analyzes some of the Czech author's writing procedures that explain such mechanism, specifically in the short-story "The new advocate". One of the fundamental traits of this hangman-narrative examined in the article is how it constitutes itself as a way out of western nihilism. For this purpose, Nietzsche's philosophy is put into dialogue in order to reach, at the end, the link with Antonin Artaud's concept of cruelty as key to understand this writing of immanence proposed by Kafka.
\end{abstract}

KEY WORDS: Franz Kafka; cruelty; absurd; Antonin Artaud. 
A destruição é o apogeu, o meio, o detalhe e o início em diversos textos de Kafka. Um carrasco latente que irradia sua gravidade, não somente nas personagens ou na trama proposta, mas no próprio exercício da linguagem. Não se trata de uma destruição estritamente punitiva, gratuita, mas, antes, de uma destruição que se dá enquanto necessidade, inerente à narrativa: complexos labirintos imagéticos e verbais que fomentam uma nova esperança para destruí-la em seguida e assim por diante, em um ciclo catatônico. Essa necessidade edifica-se no cerne dos grandes embates humanos, em que se destaca a persistência. ${ }^{1}$ Persistir, resistir, em um embate da narrativa com sua própria autodestruição. Ou ainda, em um movimento paradoxal, de uma construção que só se dá no cerne dessa corrosão. A narrativa como o carrasco de si própria.

Podemos reconhecer aqui uma dinâmica em que as palavras buscam antes o desvio e a desorientação do que a suposta via segura da representação, conforme Georges Bataille (2015, p. 145) sugere:

Kafka sempre exprimiu seu pensamento, quando o decidiu expressamente (em seu diário ou em suas páginas de reflexões), fazendo uma armadilha de cada palavra (edificava perigosos edifícios, em que as palavras não se ordenam logicamente, mas içam-se umas sobre as outras, como se quisessem tão somente surpreender, desorientar, como se elas se dirigissem ao próprio autor, que nunca se cansou, ao que parece, de ir de espanto em extravio).

Em busca desses "extravios", o intuito do presente artigo é percorrer os meandros dessa narrativa-carrasco kafkiana, passando por aquilo que nela supõe uma destruição das transcendências sobre as quais o pensamento ocidental se edificou, apontando-nos para a denúncia nietzschiana do niilismo. Caminho este que nos levará, ao final, à proposta de um diálogo do carrasco kafkiano com a crueldade proposta por Antonin Artaud, com o propósito de aproximar conceitos, ainda que entre autores de contextos distantes.

Diante desse pressuposto, estamos em contato com uma proposta literária que, através de armadilhas sobrepostas, assassina e sacrifica a si própria, deliberadamente, para mover fendas, montanhas, impérios e olimpos pela construção de um estado absurdo. No microconto “A pequena fábula" (KAFKA, 2002), temos um breve exemplo desse universo, quando um rato

\footnotetext{
${ }^{1}$ Albert Camus (2014, p. 137) defende a universalidade da obra de Franz Kafka, na mesma medida em que assegura não se tratar de uma obra absurda em totalidade, pois tal obra contempla discussões acerca do absurdo, mas também, por exemplo, a perseverança (ainda há embate, ainda há busca por todo um "consolo sobrenatural").
} 
exerce sua nostalgia sobre um mundo vasto que comportava planos possíveis. Em um átimo fulminante e sem grandes eventos, a personagem antropomorfizada concebe sua condição claustrofóbica: suas lembranças convergem em caminhos escassos e, então, em uma ratoeira. Não obstante, as inquietações do rato são respondidas pelo ultimato do gato: "Você apenas precisava alterar a direção da corrida" (KAFKA, 2002, p. 138). Então, o ouvinte engole o pequeno roedor. O tempo kafkiano não pertence ao mundo das elucubrações e dos planos futuros, mas sim à persistência, mesmo diante do fim.

Entre linhas homicidas e suicidas, em que os escombros se encavalam, não basta o conteúdo, a própria forma narrativa do autor acompanha as diversas personagens inseridas em situações em que reina, por exemplo, "a penetração no mundo humano como submissão a um jugo, o humano como reino da necessidade e não da liberdade [...] o livre arbítrio como mera tentativa de encontrar uma saída" (KOTHE, 1989, p. 11). Tal narrativa-carrasco, que abdica de um enredo linear e aditivo, de construções afetivas para tangenciar a condição humana, e que age antes por destruição, conforme dirá Maurice Blanchot (1981), encontra, para alguns leitores célebres de Kafka, o absurdo como força motriz, como é o caso da leitura de Albert Camus.

A gênese deste estado absurdo é descrita de diversas formas em $O$ mito de Sísifo de Camus. Contudo, há uma constante, uma relação de dualidade que é explicitada na frase: "O absurdo nasce desse confronto entre o apelo humano e o silêncio irracional do mundo" (CAMUS, 2014, p. 39). Ao longo do ensaio, nascimento e definição do termo misturam-se, como, por exemplo, quando o autor delineia o estado absurdo como "o espírito e o mundo apoiados um no outro sem poderem se abraçar" (CAMUS, 2014, p. 49). Essa fenda irreparável procede por uma lógica bizarra e violenta, de causa pelo efeito e efeito pela causa - o absurdo consiste em tal ciclo catatônico. Todos os dias, o zero bate à porta e o homem defronta-se com a pequenez, com a morte, com a gratuidade e com um plano divino inalcançável a nossa prisão corpórea, ao mesmo tempo em que remonta com ambição aos grandes embates da humanidade na procura por sentido, ou, menos ainda, na procura por salvação.

K., em O Processo, encontra sua jornada por sentido através do desejo pela absolvição. A própria jornada se transforma em um sentido impossível, em uma liberdade tragicômica, em que predomina a constante tarefa de confrontar a culpabilidade imposta no nascimento. A responsabilidade do homem é da ordem do agrilhoamento desde o momento em que a vida é orgânica, heterogênea e faminta. A que isso equivaleria senão, como sugere a trama de K., ao fato de que as necessidades da humanidade nos culpabilizam por fazermos parte deste mundo, 
pois, grosso modo, deveríamos ter ferramentas para alterá-lo, ou em condições vis, aceitá-lo? Não somente a humanidade, mas a própria potência, o próprio desejo inflige esse movimento, essa relação com o mundo.

À primeira vista, temos uma resolução individualista: em prol do alívio, nega-se a relação com o mundo. Impraticável para Kafka, o espaço de reclusão é ilusório:

Não é necessário sair de casa. Permaneça em sua mesa e ouça. Não apenas ouça, mas espere. Não apenas espere, mas fique sozinho em silêncio. Então o mundo se apresentará desmascarado. Em êxtase, se dobrará sobre os seus pés (KAFKA, 2011, p. 208)

Esse estado absurdo na obra kafkiana, para Camus, reverbera-se não pela recusa, mas pela perseverança:

E, com uma fé desconcertante, tentará exercer a função que lhe confiaram [...]. Cada capítulo é um fracasso. E também um recomeço. Não se trata de lógica, mas de perseverança. Na amplitude dessa teimosia está o trágico da obra. Quando K. telefona para o Castelo, ouve vozes confusas e misturadas, risos vagos, chamados remotos. Isso basta para alimentar sua esperança, como sinais que surgem nos céus estivais ou essas promessas do anoitecer que constituem nossa razão de viver" (CAMUS, 2014, p. 132).

Essa passagem diz respeito ao $O$ Castelo, mas poderia ser estendida aos outros romances, como também aos contos, principalmente se levarmos o caráter da obra kafkiana em sua totalidade como um empreendimento literário nos moldes do que aqui se propõe designar por narrativa-carrasco. Um ciclo de autodestruição e recomeço, sempre refeito, nessa "teimosia" que insiste no fracasso enquanto método de criação da escrita. A teimosia da narrativa kafkiana é essa que responde a uma necessidade existencial profunda, vocacional, como lemos em seu diário, mas, ainda, como trata Blanchot: "Kafka buscou com todas suas forças ser escritor. Desesperou-se cada vez que se viu impedido de o tornar-se" (1981, p. 76). Uma obsessão, diz Blanchot, que o leva a uma incessante busca pelo literário, tomado numa concepção segundo a qual não se deve separar artesanato, técnica, preocupação estética e destinação espiritual: uma verdadeira experimentação, como defendem Deleuze e Guattari (1975, p. 14) acerca de Kafka, e experimentação como algo vital.

Há, portanto, um necessário exercício com a escrita, em que o escritor se engaja com todo seu corpo, "um escritor não é um homem escritor, é um homem político e um homem máquina e um homem experimental” (DELEUZE; GUATTARI, 1975, p. 15). Essa máquinaKafka, experimentalmente, submete-se a uma destruição, funciona por meio de uma espécie de autossacrifício, baseado em uma intuição de que, após a destruição e, justamente, contando com 
ela, algo poderá ser edificado. É nesse sentido que, confinada na destruição e na desolação, a fé é um elemento que pode chamar a atenção. Kafka, em um de seus aforismos, ilustra:

\footnotetext{
'Não se pode dizer que estamos carentes de fé. O simples fato de nossa vida é, por si só, inesgotável em seu valor de fé.'

'Seria isso um valor de fé? Não é possível não viver.'

'Já nesse não é possível reside a força insana da fé; é nessa negação que ela assume sua forma'. (KAFKA, 2011, p. 208).
}

Na noite sem fim, no seio da impossibilidade, o corpo caminha em busca de uma saída, de uma redenção; o corpo sem a consciência do próprio corpo e de seus desejos, em um labirinto vicioso. Não há brio e rebeldia em uma potência que se dinamiza através de um movimento inócuo em um espaço de alienação. Por quais razões esse corpo continua a se movimentar, por quem esse corpo continua a se movimentar, qual o alcance de seus tentáculos, qual o fruto dessa fé? Ante semelhantes indagações, Camus (2014, p. 128) discorre: “O espírito projeta no concreto sua tragédia espiritual. E só pode fazê-lo por meio de um paradoxo perpétuo que dá às cores o poder de expressar o vazio e aos gestos cotidianos a força de transmitir as ambições eternas".

No entanto, essa narrativa-carrasco conforma-se em ser reflexo da perseverança pelas ambições eternas? Ela conservaria em si uma busca transcendente?

\section{Motor de aparências}

Lembremos do conto curto "O Novo advogado" (KAFKA, 1999), em que uma nova trajetória para Bucéfalo é narrada. O famigerado cavalo de Alexandre, o Grande, cansado da "pressão do lombo do cavaleiro nos flancos" (KAFKA, 1999, p. 11), procura conforto na ordem dos advogados e em seus códigos. Podemos tomar este inusitado texto, mais um em que o escritor tcheco utiliza de antropomorfismo, como exemplo de uma narrativa-carrasco.

Esse cavalo tinha uma condição servil em um antigo mundo e nos deparamos com uma trajetória que, à primeira vista, pode ser tomada como satisfatória, mas aqui se denota como absurda. Neste ponto, vale uma ressalva: do mesmo modo que a piada explicada perde sua força, pois a quebra de expectativa é anulada e o vínculo com o ouvinte idem, a ironia perde seu valor quando usurpada pela indicação de sua existência por quem a fez. Ignoremos esse apontamento para ressaltar a escolha por "antigo mundo" como ironia. Esse conto separa dois tempos (passado e presente) e dois planos (como veremos adiante), através das aparências do objetivo. Uma espécie de objetivo geral da humanidade ocidental: antes definido como a 
inalcançável Índia pelo monarca munido de sua espada, e, no tempo presente do conto, posto também como inalcançável, mas situado na indefinição.

[...] as portas estão deslocadas para um lugar completamente diferente, mais longe e mais alto; ninguém mostra a direção; muitos seguram espadas, mas só para brandilas; e o olhar que quer segui-las se confunde (KAFKA, 1999, p.12)

Os tempos são diferentes por quem e pelo modo com que definem o objetivo, sendo prioritariamente semelhantes na essência: a do objetivo inalcançável. No texto, é claro que Bucéfalo procura paz, mas a pergunta é: onde? O animal, servo dos desejos de Alexandre, abdica das lutas alheias para, então, encontrar saída na burocracia, no labor alienado (a ironia e o humor estão na base da lógica narrativa deste texto). Após compreender sua ausência de potência e sua submissão, ele se destitui novamente de sua potência para moldar-se a um novo cenário, no qual, aparentemente, julga-se livre, ou, pelo menos, próximo da salvação. Nesse texto, a própria narrativa não parte da reflexão sobre a condição propriamente dita de Bucéfalo, mas do detalhamento dela, como se a impossibilidade da personagem partisse também da impossibilidade dessa história definir rumo concreto.

Concreto não, suspeito sim. Essa história define um rumo: o plano inalcançável que podemos aqui designar como transcendente. Bucéfalo é impossível, pois sua busca também o é. Bucéfalo encontra-se tal qual o agrimensor K. em $O$ Castelo, onde podemos identificar uma motivação teológica da personagem em ser admitida no castelo, que é posto como esse plano divino - a admissão não ocorre e provavelmente não a teríamos mesmo que o romance fosse finalizado (a obra de Kafka clama por esse intento). Se $O$ Processo é uma retaliação, um ajuste de contas com esse plano inalcançável, $O$ Castelo é uma persuasão para a aceitação do agrimensor neste plano.

Para tal análise, podemos nos apoiar no diagnóstico nietzschiano da profunda crise na qual se encontra a cultura do Ocidente desde o século XIX, porém, em verdade, desde a instituição da Metafísica pelos gregos enquanto fundamento. Aquela do niilismo, tido por Nietzsche como a própria essência da história ocidental da filosofia e da cultura. Para isso, salientamos a reflexão de Peter Pál Pelbart no que se refere às facetas do niilismo na obra nietzschiana, considerando que esse termo faz parte de uma travessia, ou seja, parte de um processo histórico da "Antiguidade, desde Platão, e prolongado no Cristianismo, e um segundo movimento, inverso, corresponde à perda desse eixo metafísico, sobretudo na Modernidade":

Meu ponto de partida será uma pequena frase extraída de $O$ Anticristo. 'Se se põe o centro da gravidade da vida, não na vida, mas no além - no nada --, tirou-se da vida 
toda a gravidade'. Temos aí exposta a lógica que enfeixa boa parte do pensamento de Nietzsche a respeito do niilismo. O niilismo começa com um deslocamento do centro da gravidade da vida em direção a uma outra esfera que não ela mesma - o resto é consequência. Para dizê-lo de maneira mais direta: o niilismo consiste em uma depreciação metafísica da vida a partir de valores considerados superiores à própria vida, com o que a vida reduzida a um valor de nada, antes que estes mesmos valores apareçam, segundo um processo de desvalorização, naquilo que eram de início 'nada'. Temos ai vários momentos encavalados. E, de fato, com o termo niilismo Nietzsche abraça um longuíssimo arco histórico-filosófico, em que se deixa ler a ascensão dos valores morais, o modo pelo qual esses valores vieram a valer no transcurso de nossa cultura socrático-cristã, assegurando-lhe uma finalidade e um sentido, mas ao mesmo tempo denegrindo a existência. E o processo pelo qual caíram em descrédito, deixando entrever que a verdade desses valores, desde o início, era da ordem da ficção. Se o pensarmos radicalmente, Nietsche quer dizer que a história do Ocidente foi construída sobre fundamentos niilistas, com o que o niilismo dos fundamentos não deixar de vir à tona, cedo ou tarde, no transcurso dessa história, pondo em xeque a construção em seu conjunto e a própria ideia de fundamento (PELBART, 2016, p. 103).

Eis que a perda de gravidade ocorre: o intervalo vida (nascimento \& morte) foi fracionado por séculos. Foi categorizado em duas partes opostas em valores e incompatíveis na ordem experiencial: o sublime do transcendente (inalcançável e perfeito) e o miasma da terra e do corpo.

Diante desse método platônico-cristão, a prisão do corpo no homo sapiens é violentada por suas ambições e projetos: a razão, a consciência, o Paraíso, a pura ideia, a redenção. Razoemos, como uma composição orgânica - multifacetada, colônia de microuniversos bacterianos, soerguida por uma complexa gama química \& física de relações infinitesimais não somente se define como único e consciente, mas separa suas faculdades do pensamento de toda a materialidade que lhe serve de motor? Mais além, isola a própria existência em um universo insuficiente, suprassensível: "O mundo verdadeiro, inalcançável, indemonstrável, impossível de ser prometido, mas, já enquanto pensamento, um consolo, uma obrigação, um imperativo" (NIETZSCHE, 2019, p. 25).

Essa humanidade sofre por masoquista demência metódica; rejeita seu corpo em nome de uma ideia perfeita, absoluta, de um mundo sem contorno - pois não há contorno em Deus, no que concebe a ideia pura, e em sua verdade.

\footnotetext{
Quando estiver unido a Vós com todo o meu ser, em parte nenhuma sentirei dor e trabalho. A minha vida será então verdadeiramente viva, porque estará toda cheia de Vós. Libertais do seu peso aqueles que encheis. Porque não estou cheio de vós, sou ainda peso para mim (AGOSTINHO, 1973, p. 214)
}

Confissões de quem não pode estar repleto de Deus, pois Deus, como aqui a ideia e o pensamento, são pertencentes a um plano contrário ao plano sensível e do corpo. Santo Agostinho sofre ao sentir o peso de si mesmo por existir na prisão corpórea, enquanto almeja o 
plano transcendental. Nessa linha, o trabalho representa o intervalo vida, e somos miseráveis nessa etapa, a única que conhecemos empiricamente. Não há esperança. Todo esse custoso trabalho é decadência, pois ele se dá em um plano escasso; o nosso corpo é insuficiente para nós mesmos. "Olhai, eu não escondo minhas feridas. Vós sóis o médico, e eu o enfermo; sois misericordioso e eu miserável" (AGOSTINHO, 1973, P. 214)

Romper com este paradigma é propor possibilidades, conflitos, destruições e construções. Uma filosofia do corpo, tal como a de Nietzsche, é uma filosofia plural e presente; a nossa potência é forma de interpretação e de intervenção na realidade. A priori, rejeitamos a ideia de poder (potência), como se ele fosse o mal em sua essência. Devemos sofrer ante a ideia de sermos soberanos em nossas vidas; devemos temer, acima de tudo, dentro desses pressupostos supracitados.

Chama-se cristianismo a religião da compaixão. - A compaixão está em oposição a todas as paixões tônicas que aumentam a intensidade do sentimento vital: tem ação depressora. $\mathrm{O}$ homem perde poder quando se compadece. Através da perda de força causada pela compaixão o sofrimento acaba por multiplicar-se (NIETZSCHE, 2019, p. 19).

Essa compaixão, em específico, é a capacidade de colocar-se no lugar do outro; porém, de uma maneira já pré-definida. Para uma filosofia do corpo nos moldes nietzschianos, essa paixão é uma ilusão e, consequentemente, prisão. A potência tem de estar em nossas mãos para gerirmos nossos próprios valores, nossos pilares, nossos entes. Relacionarmo-nos com nossos instintos e pulsões, com a pluralidade do corpo, é relacionar-se com a eterna mutação da realidade. Comungar o sofrimento é difundir o espírito de rebanho: enclausurar nossa potência e transferir nossas qualidades medicinais para um plano uno, inalcançável e opressor. Diante da visão de um plano absurdo (observemos como as exemplificações do absurdo propostas por Camus trabalham nesse sentido), tal qual o método platônico-cristão, a resposta primeira da civilização é o niilismo; a dor incomensurável e o cansaço patológico de rejeitar um pressuposto sem deter ferramentas para novos caminhos. Nietzsche verte o corpo, gama complexa de impulsos e forças em constante conflito, em ferramenta de ação na própria vida, mesmo que contraditória. Tempos depois de Nietzsche, Emil Cioran, em uma linha semelhante de pensamento, diz:

Tenho certeza que Jesus crucificado invejou o destino do mais anônimo dos homens e, se pudesse, teria se retirado para o canto mais escuro do universo, onde ninguém mais viria lhe pedir esperança ou redenção (CIORAN, 2012, p. 113) 
O filho de deus inveja esse homem ordinário, pois seu anonimato é liberdade; e sua razão, instrumento do próprio corpo. Este homem é enfermo e médico simultaneamente - é potência, no sentido nietzschiano. Ele detém seu próprio destino, e mesmo que este possa implicar em dores ou desgraças, a perseverança é o valor maior nessa relação. Ao negarmos a potência e o corpo, negamos ferramentas que modificam a condição, seja ela qual for. Condição essa que reside neste mundo, o único que compartilhamos.

A grande força dessa suposta narrativa-carrasco presente na obra de Franz Kafka é repetidamente demonstrar essa prisão, que consiste em um longo jogo de sobrevivência pela escolha de novos planos, de novas salvações, mesmo que provisórias e locais. Essas escolhas são muito bem iluminadas pela crítica ao método platônico-cristão, que pode ser identificado nas mais variadas formas de nossa sociedade, como Peter Pál Pelbart salienta:

Assim ao anunciar a derrocada do mundo suprassensível da tradição metafísica, da
qual a figura de Deus não passa de uma concreção histórico-religiosa, Nietzsche toma
o cuidado de indicar seus sucedâneos modernos, que vão tentar preencher função
similar, oferecendo-se como centros de gravidade e pretendendo estabelecer objetivos
e assegurar sentidos como uma autoridade equivalente àquela anteriormente atribuída
à esfera humana. Seja a Consciência, a Razão, a História, o Coletivo, e ora fazendo
cintilar a miragem do Imperativo Moral, do Progresso, da Felicidade ou da
Civilização." (PELBART, 2016, p. 105).

A motivação de Bucéfalo é peculiar na medida em que podemos diagnosticar essa busca incessante pelo plano ideal, ou melhor, pela suposta voz acalentadora de um mundo prometido, mas que tem como maior particularidade a irracionalidade. Não há formulação na busca, apenas um ato de perseverança contínua diante a imposição da vida. Mesmo que esteja livre da guerra impossível de Alexandre Magno, mesmo que a sociedade presente esteja distante do objetivo sem rosto, brandindo espadas sem direção, a salvação de Bucéfalo denota-se também em um plano ideal: os códigos, no caso, como sugere o texto, os códigos das leis. Kafka não explicita ou descreve os códigos, pois eles são intocáveis, não pertencem ao nosso domínio; são tão misteriosos para nós, leitores, como para Bucéfalo e para o próprio conto. Quanto tempo resta para a personagem nesse conforto virtual ter de procurar outra aparência, outro ler e virar "as folhas dos nossos velhos livros" (KAFKA, 1999, p. 11)? As personagens kafkianas defrontamse com esse cenário absurdo de luta constante pelo possível afeto desse motor de aparências, que tem como produtos notáveis "a Consciência, a Razão, a História, o Coletivo, [...] a miragem do Imperativo Moral, do Progresso, da Felicidade ou da Civilização” (PELBART, 2016, p. 105). 
Ainda no início, o conto propõe um narrador ativo, como se lesse uma ata: "Temos um novo advogado, o dr. Bucéfalo. Seu exterior lembra pouco o tempo que ainda era o cavalo de batalha de Alexandre da Macedônia. Seja como for, quem está familiarizado com as circunstâncias percebe alguma coisa" (KAFKA, 1999, p. 11). Partindo deste apontamento, no fim do texto, quando o autor escolhe a frase "dos nossos velhos livros" (ibid.), ou no começo quando utiliza a palavra "exterior" para denotar o corpo não-humano do Novo Advogado, Bucéfalo é marginalizado pelo narrador do nosso universo, mesmo que este universo não nos seja cognoscível. Eis parte da grande ironia: um jogo de mal-estar, onde as personagens kafkianas - do agressor ao agredido - encontram-se no centro energético desse motor de aparências, que se dá na fabricação contínua de novos fundamentos para perseverar o sentido na vida. O que ele nos demonstra senão que esse sentido está em um campo linguístico tão distante, graças aos acavalamentos ininterruptos de costumes gerados por axiomas e deificações, que a origem de nossos desejos são espasmos, tal qual a sociedade um cancro espasmódico? Em cada quarto, em cada porta, em cada retrato, em cada memória, uma nova tentativa. Todavia, todas elas como uma dor inominável de não conceituar, por exemplo, a Felicidade, a Identidade ou o Imperativo Moral, mas somente sua busca. David Foster Wallace aponta para semelhante caminho ao refletir sobre o humor em Kafka:

[...] verdadeira piada fundamental em Kafka: a de que o esforço terrível de estabelecer um self humano resulta num self cuja humanidade é indissociável desse esforço terrível. De que a jornada interminável e impossível rumo ao nosso lar é, na verdade, o nosso lar". (WALLACE, 2012, p. 235)

Ainda há mais uma ironia no antropomorfismo de Bucéfalo, que é aceito pelos homens (na figura do narrador) apenas sob a condição de estrangeiro. A isso poderíamos associar uma declaração que Kafka, reportada por Gustav Janouch, segundo a qual a natureza humana é a prisão da qual o homem quer se libertar, mesmo que pela imaginação; explicação que o autor teria dado a respeito do protagonista de A Metamorfose, que, tal qual Bucéfalo, trata-se de um animal não-humano:

Cada um vive atrás das grades que que carrega consigo. Eis por que tantos livros falam hoje de animais. Isso exprime a nostalgia de uma vida livre, natural. Mas a vida natural para os homens, é a vida do homem. Contudo, ninguém vê isso. Ninguém quer ver. A existência humana é demasiada penosa, por isso queremos nos livrar dela, ao menos pela imaginação". (JANOUCH, 2008, p. 22)

Para o que nos interessa, remarquemos que Kafka não parece querer quer nos aliviar da pena com seu texto. Pelo contrário: ele nos faz vibrar a mescla entre o animal e o homem como 
partes incompletas de seus designíos: a) o narrador e os advogados, em um exercício de falsa comiseração, tentam encontrar sua própria identidade em um animal a partir do exercício de diferenciação; b) Bucéfalo procura, na salvação indefinida do homem, a sua própria salvação.

Portanto, há uma ridicularização humorística do projeto humano: o que nos tornamos em contraposição ao que queríamos nos tornar, ou daquilo que desejávamos nos afastar. É nesse cenário de fracasso que nos deparamos com uma busca com fim nela mesma, e isso é uma contradição, já que o limite das buscas se dá sobretudo na capacidade de caminhar, não na capacidade de concretização.

Voltemos a Friedrich Nietzsche, que, ao analisar este método platônico-cristão, não está debatendo o Deus cristão em si. O filósofo discute o processo histórico que resulta nessa separação em dois planos transcendentes entre si e a que isso conduz em nossas existências (palavras, valores, ídolos, etc.), na construção de nossa cultura no Ocidente. Nossa sujeição é diagnosticada, nossos embates diários são formulados a partir de estruturas vazias.

\begin{abstract}
A outra idiossincrasia dos filósofos não é menos perigosa: ela consiste em confundir o último com o primeiro. O que vem no final - infelizmente, pois não deveria jamais vir! --, os "conceitos mais elevados", isto é, os conceitos mais gerais, mais vazios, eles põem no começo, como começo. Novamente, isto é apenas expressão de seu modo de venerar: o mais elevado não pode ter se desenvolvido a partir do mais baixo, não pode ter se desenvolvido absolutamente... Moral: tudo o que é de primeira ordem tem de ser causa sui [causa de si mesmo] A procedência de algo mais é tida como objeção, como questionamento do valor. Todos os valores mais altos são de primeira ordem, todos os conceitos mais elevados, o ser, o incondicionado, o bem, o verdadeiro, o perfeito - nenhum deles pode ter se tornado, tem de ser causa sui. Mas também não pode ser dissimilar um do outro, não pode estar em contradição consigo... Assim, os filósofos chegam ao seu estupendo conceito de "Deus" ... O último, mais tênue, mais vazio é posto como primeiro, como causa em si [...] (NIETZSCHE, 2017, p. 22).
\end{abstract}

Os três planos ideais (Identidade do narrador e da ordem geral dos advogados; a guerra de Alexandre, o Grande; e os Códigos) escritos como objetivos no conto são causa sui, o que somente catalisa a gênese desse estado absurdo presente na narrativa-carrasco. Até mesmo a "razão", composta, a priori, na concatenação, comporta-se inversamente, como um “irracionalismo em nome da razão" (SOUZA, 2017, p. 120). Nossos códigos e livros são exemplificações de meros exercícios gráficos. Qual é o real valor desse conforto? Bucéfalo é colocado nessa situação de cenários aparentemente distintos e sucumbe à não confiabilidade do narrador. Ele mesmo, personagem histórico das guerras e conquistas, somente é admitido graças à compaixão da ordem dos advogados, como o próprio narrador destaca: “[...] ele de qualquer modo merece boa vontade" (KAFKA, 1999, p. 11), semelhante a quando foi domado por Alexandre, que observou a origem de sua violência: o medo de sua própria sombra. Logo, 
podemos nos relacionar com a gênese dessa narrativa-carrasco nesse pequeno conto. Mais uma personagem condizente à Sísifo, perseverante, e no auge de suas vãs escolhas, em sua ilusória resolução, a própria narrativa soergue, como a sombra de um enorme titã, para se negar com seus códigos, com suas tramoias, à serviço de uma irracionalidade, ou melhor, do vazio; a escrita que procura assassinar e "suicidar-se".

Então, regressemos à pergunta: essa narrativa-carrasco conforma-se em ser reflexo da perseverança pelas ambições eternas?. O próprio exercício de construir e descontruir o texto dessa maneira, ou melhor, essa escolha de estilo, não denota por si só o colossal desconforto em ignorar tais lutas, próprias da situação do absurdo? O fato de não eleger novos ídolos, de não chegar a uma substituição final das transcendências, em Kafka, não impede que a narrativa persevere. Ao contrário, essa perseverança aqui é o movimento que, nesse autodesfazimento perpétuo, parece assegurar alguns vestígios vivos de uma revolta em nome de algum objetivo possível.

\begin{abstract}
Não acabo nada porque não tenho tempo e dentro de mim há essa urgência tão grande. Se o dia inteiro estivesse livre e essa inquietação matinal em mim pudesse aumentar até o meio-dia e se cansar até a noite, então eu poderia dormir. Mas assim, resta para essa inquietação no máximo apenas uma hora do crepúsculo, ela se intensifica um pouco, então é oprimida e escava minha noite inútil e danosamente. Aguentarei isso por muito tempo? E terá alguma finalidade aguentá-lo, obterei tempo afinal? (KAFKA, 2018, p. 84)
\end{abstract}

Toda a tensão do autor está em detalhar, vasculhar e fazer persistir a inquietação; e não em solucionar. Pois, no caminho da solução, o motor de aparências tornar-se-ia uma resposta final, mais uma vez, como o lobo que se veste de cordeiro. Kafka ressalta:

Tudo é fraude: buscar o mínimo de ilusão, permanecer no nível usual, buscar o máximo. No primeiro caso, frauda-se o bem, na medida em que se deseja tornar fácil demais sua conquista; o mal, na medida em que é colocado em condições de luta excessivamente desfavoráveis. No segundo caso, o bem é fraudado na medida em que não se luta para alcançá-lo, nem mesmo naquilo que é terreno. No terceiro caso, frauda-se o bem na medida em que a esperança é torná-lo impotente com sua máxima intensificação. Seria preferível, nisso tudo, o segundo caso, pois sempre se frauda o bem e não o mal; neste caso, pelo menos na aparência (KAFKA, 2011, p. 197).

\title{
Crueldade e narrativa-carrasco
}

A escrita não se dá a partir de uma ideia premeditada em sua completude, a escrita é um processo imanente e consegue delimitar algum objetivo proposto. É pelo fato de o processo ter criado e desatado tais nós, para em seguida ver-se envolvido em novos nós, novos impasses, e assim indefinidamente. Aqui o termo literatura encontra o paradoxo enunciado por Blanchot: é 
cúmplice do que a ameaça, e vice-versa: "Ela se sacrifica e esse sacrifício, longe de a fazer desaparecer, a enriquece de novos poderes" (1981, p. 92). Trata-se, em Kafka, por Blanchot, de uma destruição que constrói, de uma construção que se dá ao rés de sua própria dissolução.

É neste sentido que essa narrativa-carrasco de Kafka, tal como buscamos propor, encontraria um interlocutor singular em Antonin Artaud e na sua noção de crueldade. Tal aproximação nos é sugerida, primeiramente, pela inegável crueldade que há em Kafka em nos dispor tais desertos, inegável sadismo em nos demonstrar e perpetuar um tempo insólito de revolta impotente. Um pequeno diálogo entre o autor e Max Brod ilustra isso:

Recordo-me de uma conversa com Kafka, cujo ponto de partida foi a Europa contemporânea e a decadência da humanidade. Somos, disse ele, pensamentos niilistas, pensamentos suicidas que surgem na cabeça de Deus. Essa frase evocou em mim a princípio a visão gnóstica de mundo: Deus como um demiurgo perverso, e o mundo como seu pecado original. Oh não, disse ele, nosso mundo é apenas um mau humor de Deus, um dos seus maus dias. Existiria então esperanças, fora desse mundo de aparências que conhecemos? Ele riu: há esperança suficiente, esperança infinita -mas não para nós. (BENJAMIN, 2012, p. 152).

Essa dualidade é pujante: a esperança como perseverança no absurdo e a impossibilidade de esperança diante algum plano transcendental. E é nela que reside o que podemos chamar de crueldade em Kafka, remetendo-nos ao tratamento do termo a que dará Artaud. $\mathrm{O}$ autor francês proclama colericamente em sua obra uma luta contra inimigos muito semelhantes aos kafkianos e nietzscheanos, todos da família das transcendências da nossa tradição metafísica, declarando guerra contra inúmeras facetas do status quo: “Quem não sente a bomba cozida e a vertigem comprimida não é digno de estar vivo" (ARTAUD, 2011, p. 284). Declarando guerra até mesmo aos órgãos, em seu funcionamento biológico e medicalizado, ao organismo em sua sistematização hierarquizada e obediente às normas, Artaud busca a liberação do corpo, tantos séculos domado e rejeitado pela cultura Ocidental:

Porque metam-me na tal camisa-de-forças se quiserem, mas não há nada mais inútil que um órgão.

Quando lhe derem um corpo sem órgãos, vão libertá-lo de todos os seus automatismos e devolvê-lo à sua verdadeira liberdade. (ARTAUD, 2019, p. 198)

Submetido tantas vezes a tratamentos psiquiátricos, Artaud escreve, com lucidez, nessa mesma transmissão radiofônica ("Para acabar com o juízo de deus"): “Eu fui enlouquecido e tetanizado durante anos". (2019, p. 204) E, para não adoecer, dizia, era preciso destituir a ordem orgânica, como a representação, a mística e a metafísica. Era preciso buscar o corpo, em sua 
realidade concreta e visceral: "a vida passional e concreta integral do corpo humano" (p. 200). A proposta levada a cabo de um "teatro da crueldade" por ele teria como pressuposto a destruição dos organismos (inimigos do corpo concreto), enquanto ordens instituídas, e a negação da representação enquanto motor da cena e do texto:

A realidade ainda não está construída porque os órgãos verdadeiros do corpo humano ainda não foram compostos e colocados.

O teatro da crueldade foi criado para terminar esta colocação, e para provocar, por uma dança nova do corpo humano, a ruína deste mundo de micróbios que não passa de vazio coagulado.

O teatro da crueldade quer por a dançar pálpebras par a par com cotovelos, rótulas, fêmures e dedos dos pés,

e que o vejam. (ARTAUD, 2019, p. 289-290)

Para isso, Artaud propõe em seu teatro uma blitz, uma destruição dos afetos preconcebidos do público através de um jugo violento sobre a desproporção destes planos. $\mathrm{O}$ teatro deveria ser tão "real" quanto um assassinato ou uma batida policial. A crueldade estaria em propor um acontecimento em tempo real, aos espectadores, a ser vivida por eles enquanto uma verdadeira apresentação, inédita, inesperada - e não uma representação. Um despertar dos sentidos do corpo em um "atletismo afetivo", do qual o ator deveria ser mestre. A arte deveria ser assim cruel, crua, como a vida. Destituída de transcendências, de planos ideais ou acessórios, a arte deve ser crueldade: imanência, processo na imanência, como no absurdo kafkiano.

Por suas vias, pode-se dizer que Artaud partilha de um pensamento do corpo próximo ao de Nietzsche, concebendo em sua crueldade uma tresvaloração de todos os valores: ${ }^{2}$

Uso a palavra crueldade no sentido de apetite de vida, de rigor cósmico e de necessidade implacável, no sentido gnóstico de turbilhão de vida que devora as trevas, no sentido da dor fora de cuja necessidade inelutável a vida não consegue se manter; o bem é desejado, é o resultado de um ato, o mal é permanente. [...] Uma peça em que não houvesse essa vontade, esse apetite de vida cego, capaz de passar por cima de tudo, visível em cada gesto e em cada ato, e do lado transcendente da ação, seria uma peça inútil e fracassada. (ARTAUD, 1999, p. 119)

De modo que é preciso ver que, por detrás de um termo aparentemente negativo, a crueldade, pulsa em Artaud um desejo de vida: uma vitalidade que busca investir contra todos aqueles valores - transcendentes, metafísicos - que, durante séculos, aprisionaram a "vida real",

\footnotetext{
2 "Apenas o excesso de força é prova de força - "Uma tresvaloração de todos os valores [...]" (NIETZSCHE, 2017, Prólogo, p. 7). O filósofo inicia o livro propondo uma guerra contra os valores estabelecidos, desde a moralidade cristã à tirania da racionalidade: "fazer perguntas com o martelo e talvez ouvir, como resposta, aquele célebre som oco que vem das vísceras infladas".
} 
aquela do corpo, a vida concreta dos afetos e dos sentidos. Trata-se de questionar o poder médico, psiquiátrico, mas também o capitalista, o religioso. É o que Kuniichi Uno, estudioso de Artaud e seu tradutor para o japonês, insistirá em diversos momentos de sua obra: "Para Artaud sempre se tratou de uma luta, de uma guerra singular contra tudo o que investia a vida em toda sua extensão" (UNO, 2018, p. 65). Da mesma forma, a narrativa-carrasco, em Kafka, liga-se ao mecanismo de uma destruição motivada sobretudo pelo desejo de construção. $\mathrm{O}$ autossacrifício da narrativa, como vimos anteriormente com Blanchot, é sua chance de criar novas potências, em uma escrita intimamente entranhada com a vida, em sua imanência. Assim como em Artaud, a crueldade consiste aqui em uma destituição da transcendência em prol do processo imanente - do corpo, da vida, da escrita; ainda que tal empreendimento implique em uma finalização jamais possível, pois que restituidora de novas transcendências. (Talvez não por acaso, supõe Blanchot, haja tantos textos inacabados de Kafka.) A crueldade aponta, em ambos casos, à corda-bamba da imanência, sua sutil e difícil sustentação, na beira do corpo e da linguagem: escritas dos limites. "A linguagem cessa de ser representativa para tender em direção a seus extremos ou seus limites" (DELEUZE; GUATTARI, 1975, p. 42).

Reencontramos aqui Kafka e seu motor de aparências; a necessidade da destruição em coexistência íntima com a construção; a escrita que se autoaniquila, em um autossacrifício criador e necessário: a narrativa que funciona sob o modo de seu próprio carrasco.

\footnotetext{
Ao aprofundar o negativo, Kafka o concede uma oportunidade de ser positivo, somente como uma oportunidade, uma oportunidade que nunca chega a realizar-se inteiramente e, através da qual, seu oposto não deixa de transluzir-se. Toda a obra de Kafka está em posse de uma afirmação que gostaria de conquistar por meio da negação, afirmação que, por se delinear, se subtrai, parece mentira e, portanto, se exclui das afirmações, tornando a afirmação novamente possível. (BLANCHOT, 1981, p. 69).
}

Dessa maneira, podemos relacionar essa narrativa-carrasco, que encontra afirmação ao registrar o absurdo, com à transição nietzschiana do niilismo passivo, aquele aqui descrito na vivência e também na análise das formas decantes de existência (fruto do método-platônicocristão), ao niilismo ativo, quando a negação ao limite se transmuta efetivamente em afirmação, ou seja, no ensaio pela construção de novos valores. Pelo menos, ao que perscruta Gilles Deleuze em Nietzsche: "No homem que quer perecer, que quer ser superado, a negação rompeu tudo o que ainda a retinha, venceu a si mesma, se tornou potência de afirmar, potência do alémdo-homem, potência que anuncia e prepara o além-do-homem" (DELEUZE, 2018, p. 222). Mas o que afirmar? A vida, ou ainda, o próprio devir como instância maior da vida: 
479. As paixões que dizem "sim". - A altivez, a alegria, a saúde, o amor dos sexos, a inimizade e a guerra, a veneração, as belas atitudes, as boas maneiras, a vontade forte, a disciplina da intelectualidade superior, a vontade de potência, agradecimento à terra e à vida - tudo o que é rico e quer dar, e gratificar a vida, dourá-la, eternizá-la, divinizá-la - toda essa potência das virtudes que transfiguram --, tudo o que aprova diz sim e procede e pratica o sim (NIETZSCHE, 2017, p. 549).

Essa transmutação do valor negativo ao afirmativo, em Kafka, opera necessariamente no detalhamento cruel do absurdo, o qual leva o escritor e seu o público ao engajamento nauseabundo quando diante, por exemplo, da resolução prática implantada no Novo Advogado: "Talvez por isso o melhor realmente seja, como Bucéfalo fez, mergulhar nos códigos. Livre, sem a pressão do lombo do cavaleiro nos flancos [...]" (KAFKA, 1999, p. 12) - na medida em que a fraude é infinita, o avesso do horror reitera a luta pela vida em caráter de denúncia, ao exemplo da análise de Camus sobre a filosofia nietzschiana:

O espírito livre destruirá tais valores ao denunciar as ilusões sobre as quais repousam, a barganha que implica e o crime que cometem ao impedir que a inteligência lúcida realize a sua missão: transformar o niilismo passivo em niilismo ativo (CAMUS, 2020, p. 99).

Somos responsáveis e agrilhoados na encenação social, e a crueldade propõe: “será, quando necessário, sangrenta, mas que não o será sistematicamente, confunde-se, portanto, com a noção de uma espécie de árida pureza moral que não teme pagar pela vida o preço que deve ser pago" (ARTAUD, 1999, p. 143). Artaud parece portar a mesma fatalidade irremediável de Kafka, e a sua crueldade emerge do cenário absurdo que transborda do seio silencioso da vida. Do outro lado, no âmago da narrativa-carrasco do autor tcheco, há também uma crueldade colossal com o leitor, que é destruído horizontalmente com o próprio texto, e é maculado pelo papel parvo que lhe é imposto na vida para, então, remoer-se pela necessária revolta, mesmo diante da morte indomável. De distintas formas, a perseverança eclode nas diferentes obras como intento máximo do registro contra as injustiças da vida - absurdo e crueldade são complementares.

\section{REFERÊNCIAS}

AgOstinho, Santo. Confissões. In: AGOSTINHO, Santo. Os Pensadores. Trad. J. Oliveira Santos, S.J. e A. Ambrósio de Pina. SJ. São Paulo: Abril S.A Cultural e Industrial, 1973. 
ARTAUD, Antonin. Linguagem e vida. Trad. J. Guinsburg, Silvia Fernandes, Regina Correa Rocha e Maria Lúcia Pereira. São Paulo: Perspectiva, 2011.

ARTAUD, Antonin. O teatro e seu duplo. Trad. Teixeira Coelho. São Paulo: Martins Fontes, 1999.

ARTAUD, Antonin. Para acabar de vez com o juízo de deus e outros textos finais (19461948). Trad. e notas de Pedro Eiras. Porto: FLOP, 2019.

BATAILLE, Georges. A literatura e o mal. Trad. Fernando Sheibe. São Paulo: Autêntica, 2015.

BENJAMIN, Walter. Magia e técnica, arte e política: ensaios sobre literatura e história da cultura. Trad. Sérgio Paulo Rouanet. São Paulo: Brasiliense, 2012.

BLANCHOT, Maurice. De Kafka à Kafka. Paris: Gallimard/ Folio, 1981.

CAMUS, Albert. O Mito de Sísifo - Incluí estudo sobre Franz Kafka. Trad. Ari Roitman e Paulina Watch. Rio de Janeiro: Bestbolso, 2014.

CAMUS, Albert. O homem revoltado. Trad. Valerie Rumjanek. Rio de Janeiro: Record, 2020.

CIORAN, Emil. Nos cumes do desespero. Trad. Fernando Klabin. São Paulo: Hedra, 2011.

DAVID, Foster Wallace. Ficando longe do fato de já estar meio que longe de tudo. Trad.

Daniel Galera e Daniel Pellizzari. São Paulo: Companhia das Letras, 2012.

DELEUZE, Gilles. Nietzsche e a filosofia. Trad. Mariana de Toledo Barbosa e Ovídio de Abreu Filho. São Paulo: n-1 edições, 2018.

DELEUZE, Gilles; GUATTARI, Félix. Kafka, pour une littérature mineur. Paris: Minuit, 1975.

JANOUCH, Gustav. Conversas com Kafka. Trad. Celina Luz. Osasco: Novo Século Editora, 2008.

KAFKA, Franz. Narrativas do espólio. Trad. Modesto Carone São Paulo: Companhia das Letras, 2002.

KAFKA, Franz. Um médico rural: pequenas narrativas. Trad. Modesto Carone. São Paulo: Companhia das letras, 1999.

KAFKA, Franz. Essencial Franz Kafka. Trad. Modesto Carone. São Paulo: Penguin Classics Companhia das letras, 2011.

KOTHE, Flávio. Formas da contradição em Kafka. In: KAFKA, Franz. Nas Galerias. Trad. Flávio R. Kothe. São Paulo: Estação Liberdade, 1989. 
NIETZSCHE, Friedrich. Crepúsculo dos ídolos, ou Como se filosofa com o martelo. Trad. Paulo César de Souza. São Paulo: Companhia de bolso, 2017.

NIETZSCHE, Friedrich. $O$ anticristo: maldição contra o cristianismo. Trad. Renato Zwick. Porto Alegre: L\&PM, 2019.

NIETZSCHE, Friedrich. Vontade de potência. Trad. Mário Ferreira dos Santos. Petrópolis: Vozes, 2017.

PELBART, Peter Pál. O avesso do niilismo: cartografias do esgotamento. São Paulo: n-1 edições, 2013.

UNO, Kuniichi. Hijikata Tatsumi - pensar um corpo esgotado. Trad. Christine Greiner e Ernesto Filho. São Paulo: N-1 Ed., 2018.

Artigo submetido em: 07 jul. 2021

Aceito para publicação em: 28 set. 2021

DOI: https://dx.doi.org/10.22456/2238-8915.116597 